\title{
Enzyme-mediated synthesis of ceramic materials
}

\author{
Hidero UNUMA, ${ }^{\dagger}$ Yuta MATSUSHIMA and Takahiro KAWAI \\ Graduate School of Science and Engineering, Yamagata University, 4-3-16 Jonan, Yonezawa, Yamagata 992-8510
}

\begin{abstract}
Some enzymes catalyze the formation of precipitants of metal ions, and some others directly interact with metal-containing precursors. Such enzymes allow the synthesis of inorganic solids under mild conditions. Due to the nature of enzymatic reactions, enzyme-mediated ceramic synthesis techniques can facilitate (1) site-selective ceramic deposition, (2) low temperature ceramic synthesis, (3) intact combination of ceramics with heat-sensitive materials, and sometimes (4) synthesis of metastable phases. The morphology of the resultant ceramics can be tailored in many ways by immobilizing enzymes onto various templates. So far, successful cases have been reported in preparing thin film coatings, hollow micro- or nanospheres, multi-layer stacking, nanotubes, 2D patterns, honeycombs, 3D replicas of biominerals, and so on. Enzyme-mediated ceramic synthesis provoked the emergence of a new type of processing technique which employs proteins or peptides as the mediators. Practical applications of enzyme- or peptide-mediated ceramics are on the horizon in many fields, such as biomaterials, enzyme immobilization supports, and enzyme sensors. This article presents a comprehensive survey of the recent advances of enzyme-mediated ceramic synthesis and related techniques as well as future outlook.
\end{abstract}

(C2011 The Ceramic Society of Japan. All rights reserved.

Key-words : Enzyme, Peptide, Bio-inspired, Biomineral, Morphology control

[Received May 23, 2011; Accepted June 1, 2011]

\section{Introduction}

Enzymes are protein catalysts that show both substrate specificity and reaction specificity and catalyze specific chemical reactions, including hydrolysis, reduction-oxidation, structural transfer, elimination of specific functional groups, isomerization, and bond formation, mainly in organic compounds. Enzymatic reactions naturally take place in living organisms; however, nowadays enzymes are also utilized in bioreactors to manufacture industrial products such as drugs, medicines, and agricultural chemicals, or as components of tooth pastes and detergents. Almost all enzyme-mediated chemical reactions are organic reactions, although inorganic reactions involving enzymes do exist.

The first attempted enzyme-mediated ceramic synthesis goes back to 1961, when carbonate apatite was synthesized with the mediation by carbonic anhydrase. ${ }^{1)}$ During the following four decades, enzyme-mediated ceramic synthesis was explored by a number of scientists and unique products were reported; however, the technique did not become a major area of ceramic science.

It was the discovery of a silicate synthesis enzyme, ${ }^{2)}$ silicatein, which enabled the synthesis of $\mathrm{SiO}_{2}$ or $\mathrm{TiO}_{2}$ from inorganic reagents, that attracted much attention to the advantages of enzyme-mediated ceramic synthesis. The number of research papers in this area has been mounting rapidly during the last decade. The mediation of enzymes in ceramic synthesis has brought in a number of unique advantages, such as, site-selective ceramic deposition, low temperature ceramic synthesis, or intact combination of ceramics with heat-sensitive materials. In some cases, metastable crystalline phases have been synthesized by the mediation of enzymes.

Enzyme-mediated ceramic synthesis stimulated the occurrence of a new stream of processing techniques utilizing

\footnotetext{
$\dagger$ Corresponding author: H. Unuma; E-mail: unuma@yz.yamagatau.ac.jp
}

proteins or artificial peptide sequences that are capable of precipitating ceramic materials out of aqueous solutions; there have been a number of comprehensive review articles in this regard. ${ }^{3)-8)}$

In this article, we will focus on the individual enzymes employed in enzyme-mediated ceramic synthesis, the resultant ceramic products, attempts to tailor morphology and function, and potential applications using enzyme-mediated techniques.

\section{Enzymes and ceramic products}

Enzyme-mediated ceramic synthesis techniques fall into two main categories: category I, in which precipitants of metal ions are produced by enzymatic reactions, and metal ions in solutions precipitate into oxides, hydroxides, carbonates, or phosphates; and category II, in which enzymes interact directly with metalcontaining substrates to produce ceramic materials (Fig. 1). Enzymes and ceramic products are listed in Tables $\mathbf{1}$ and 2. The most easily understandable example of category I is ureasemediated precipitation of $\mathrm{CaCO}_{3}:{ }^{27)}$ when a small amount of urease is dissolved in a solution containing $\mathrm{CaCl}_{2}$ and urea, the urea is hydrolyzed to ammonia and $\mathrm{H}_{2} \mathrm{CO}_{3}$, then $\mathrm{Ca}^{2+}$ reacts with $\mathrm{CO}_{3}{ }^{-}$, and $\mathrm{CaCO}_{3}$ precipitates out at room temperature.

The first feature unique to enzyme-mediated ceramic synthesis is that ceramic precipitation takes place at low temperatures, such as room temperature, and the apparent rate of ceramic precipitation can easily be controlled. Since enzyme-mediated ceramic products can be synthesized at low temperatures, such ceramic products can readily be combined with organic or heatsensitive substances such as proteins. For example, enzymemediated ceramics can be suitable inorganic supports of other types of enzymes. ${ }^{3)}$ Such encapsulated enzymes in enzymemediated ceramics sometimes showed higher activity than freeenzymes. ${ }^{59), 67)}$ Most enzyme-mediated precipitates are hydroxides, carbonates, or hydrated oxides, rather than non-hydrated oxides. Therefore, the precipitates sometimes need to be heattreated to convert to non-hydrated oxides. 


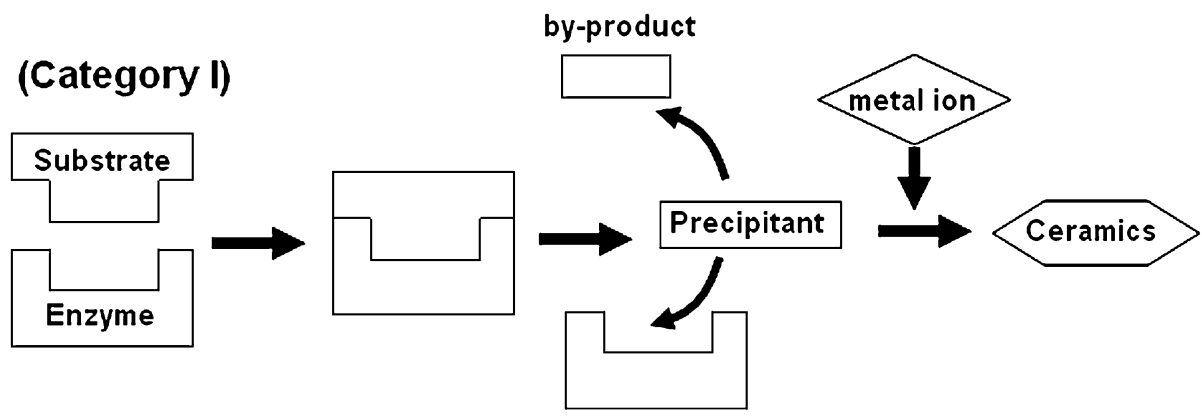

(Category II)

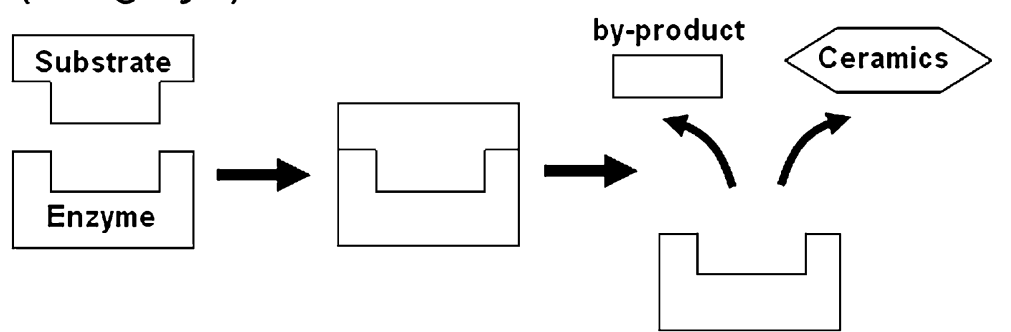

Fig. 1. Schematic representations of the ceramic formation processes mediated by enzymes in categories I and II.

Table 1. Enzymes in category I and the resultant ceramic products

\begin{tabular}{|c|c|c|}
\hline Enzyme & Precipitant & Ceramic product \\
\hline Carbonic anhydrase & Carbonate ion & Carbonate hydroxyapatite $^{1)}$ \\
\hline Alkaline phosphatase & Phosphoric acid & Calcium phosphates ${ }^{9-17)}$ \\
\hline Urease & Ammonia, carbonate ion & $\begin{array}{c}\text { Magnetite, }{ }^{18)-20)} \text { iron hydroxide, }{ }^{21,22)} \text { basic aluminium } \\
\text { sulfate, }{ }^{23)-26)} \mathrm{CaCO}_{3},{ }^{27)-29)} \mathrm{SrCO}_{3},{ }^{30)} \mathrm{BaCO}_{3}{ }^{30)} \text { calcium } \\
\text { phosphates, }{ }^{31-38)} \text { yttrium hydroxide, }{ }^{39)} \mathrm{ZnO}^{40)}\end{array}$ \\
\hline Glucose oxidase and catalase & Gluconic acid & Hydrated tin oxide ond $^{41}$ \\
\hline Lipase & Oxalic acid & Calcium oxalate 2.25 hydrate $^{42)}$ \\
\hline Artificial enzyme mimicking carbonic anhydrase & Carbonate ion & $\mathrm{CaCO}_{3}{ }^{43)}$ \\
\hline
\end{tabular}

Table 2. Enzymes in category II and the resultant ceramic products

\begin{tabular}{|c|c|c|}
\hline Enzyme & Substrate & Ceramic product \\
\hline \multirow{5}{*}{ Silicatein ${ }^{44)-46)}$} & TEOS, ${ }^{47), 48)}$ sodium metasilicate ${ }^{49)}$ & $\mathrm{SiO}_{2}$ \\
\hline & Ti-BALDH $^{50)-52)}$ & $\mathrm{TiO}_{2}$ \\
\hline & Hexafluorozirconate $^{51)}$ & $\mathrm{ZrO}_{2}$ \\
\hline & Gallium nitrate $^{53)}$ & $\mathrm{GaOOH}, \gamma-\mathrm{Ga}_{2} \mathrm{O}_{3}$ \\
\hline & $\mathrm{BaTiF}_{6}{ }^{54)}$ & $\mathrm{BaTiOF}_{4}$ \\
\hline \multirow{6}{*}{ Lysozyme } & Sodium silicate ${ }^{55), 56)}$ & $\mathrm{SiO}_{2}$ \\
\hline & TMOS $^{57)-59)}$ & $\mathrm{SiO}_{2}$ \\
\hline & TEOS $^{60)}$ & $\mathrm{SiO}_{2}$ \\
\hline & Hexafluorotitanate $^{57)}$ & $\mathrm{TiO}_{2}$ \\
\hline & Ti-BALDH $^{61)}$ & $\mathrm{TiO}_{2}$ \\
\hline & $\mathrm{Bi}\left(\mathrm{NO}_{3}\right)_{3}$ and thiourea ${ }^{62)}$ & $\mathrm{Bi}_{2} \mathrm{~S}_{3}, \mathrm{Bi}_{2} \mathrm{O}_{3}$ \\
\hline \multirow{2}{*}{ Lipase or pepsin } & TEOS $^{63)}$ & $\mathrm{SiO}_{2}$ \\
\hline & Titanium lactato- and glycolato-complexes $^{64)}$ & $\mathrm{TiO}_{2}$ \\
\hline Papain or trypsin & Ti-BALDH $^{65)}$ & $\mathrm{TiO}_{2}$ \\
\hline Papain & TMOS $^{65)}$ & $\mathrm{SiO}_{2}$ \\
\hline Catalase or glucose oxidase & Titanium sulfate $^{61)}$ & $\mathrm{TiO}_{2}$ \\
\hline Hydrolases & Alkoxysilanes ${ }^{66), 67)}$ & $\mathrm{SiO}_{2}$ \\
\hline
\end{tabular}


In category I synthesis, the rate of production of metal ion precipitants follows well-established Michaelis-Menten kinetics as expressed in Eq. (1):

$$
v=\frac{V_{\max }[S]}{K_{\mathrm{m}}+[S]}
$$

where $K_{\mathrm{m}},[S]$, and $V_{\max }$ represent the Michaelis-Menten constant, the substrate concentration, and the maximum rate, respectively. When the substrates are present in large excess compared to the enzyme, which is the general case, the rate of precipitant production can be regarded as being linearly proportional to the enzyme concentration, as in Eq. (2):

$$
v=V_{\max }=k\left[E_{0}\right]
$$

where $\left[E_{0}\right]$ and $k$ represent the enzyme concentration and the ratedetermining rate constant with respect to the production of precipitant, respectively.

By changing the enzyme concentration, therefore, the apparent rate of ceramic precipitation may be controlled. When a product precipitates out of a homogeneous solution, the homogeneous nucleation theory tells that a small number of nuclei are formed if the precipitant is supplied slowly. It should be noted, however, that when the precipitate is supplied by enzymes, the enzymes themselves sometimes act as nucleation sites ${ }^{39)}$ and the homogeneous nucleation theory is not always followed. In other words, when an enzyme is dissolved in an apparently homogeneous solution, the solution may no longer be homogeneous.

The second feature of enzyme-mediated ceramic synthesis is that the precipitates sometimes exhibit different crystalline phases, morphologies, or phase evolution behaviors than those prepared in conventional, enzyme-free methods. For example, Kato et al. ${ }^{42)}$ reported that calcium oxalate precipitated with lipase-derived oxalic acid was a 2.25 hydrate with fibrous morphology, while that precipitated under a lipase-free condition was a monohydrate with granular shapes. It has also been reported that the crystalline phases and the phase evolution upon heating of enzyme-mediated $\mathrm{TiO}_{2}$ vary depending on the types of substrate and enzyme employed. ${ }^{50), 61), 64)}$ For example, glucose oxidase catalyzes the precipitation of rutile from a titanium sulfate solution at room temperature, while catalase precipitates anatase, and lysozyme mediates the precipitation of a mixture of anatase and $\beta-\mathrm{TiO}_{2}$ in a Ti-BALDH [titanium bis-(ammonium lactato)-dihydroxide] solution. ${ }^{61)}$ Katagiri et al. reported that the crystallization behaviors of amorphous titania precipitates obtained with the aid of lipase and pepsin were not identical. ${ }^{64)}$ In addition, when native silicatein filaments were immersed in a $\mathrm{Ga}\left(\mathrm{NO}_{3}\right)_{3}$ solution, $\mathrm{GaOOH}$ precipitated at $289 \mathrm{~K}$, while a metastable $\gamma-\mathrm{Ga}_{2} \mathrm{O}_{3}$ phase, oriented along the filaments, precipitated at $298 \mathrm{~K}^{53)}$ The reasons for these peculiar phenomena are still unclear, but one hypothesis is that the amino acid residues or 3D structure of the enzyme offers preferential nucleation sites to specific crystalline phases, thereby affecting the crystalline phase and phase evolution behavior.

The third feature of enzyme-mediated ceramic synthesis is that the morphology of the ceramic products can easily be controlled by immobilizing enzymes onto various templates. In some cases the enzymes themselves act as such templates. Templates of various types and shapes have been used to synthesize thin film coatings, hollow micro- and nano-spheres, multi-layer stacking, nanotubes, 2D patterns, honeycombs, and 3D replicas of biominerals. As well as chemical immobilization using glutaraldehyde or carbodiimides, physical immobilization within gels of alginate or chitosan has also been used. Since ceramic

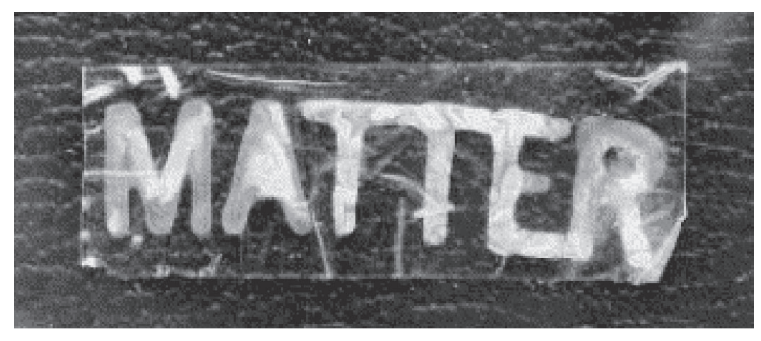

Fig. 2. Alkaline phosphatase-mediated collagen/calcium phosphate composite sheet in which calcium phosphate was deposited only in the enzyme-loaded area. Reprint from Ref. 12 with permission from Elsevier.

precipitation takes place in the vicinity of the immobilized enzymes, the enzymes are buried by the precipitates as precipitation proceeds; eventually, precipitation terminates unless the enzyme immobilization process is repeated. In other words, ceramic synthesis mediated by immobilized enzymes is siteselective and self-terminating.

\subsection{Alkaline phosphatase}

Alkaline phosphatase catalyzes the hydrolysis of phosphate esters into inorganic phosphate ions and alcohols, diols, or glycols under alkaline conditions, as expressed in Eq. (3):

$$
\mathrm{R}-\mathrm{O}-\mathrm{PO}(\mathrm{OH})_{2}+\mathrm{H}_{2} \mathrm{O} \rightarrow \mathrm{ROH}+\mathrm{H}_{3} \mathrm{PO}_{4}
$$

where $\mathrm{R}$ represents an alkyl group. When reaction 3 takes place in the presence of calcium ion for instance, calcium phosphates are precipitated. Under alkaline conditions, the calcium phosphate phase is usually hydroxyapatite.

In the early work of Banks and co-workers, ${ }^{9)}$ alkaline phosphatase was immobilized onto reconstituted collagen tape with dimethyl suberidiimide, and hydroxyapatite was biomimetically precipitated onto the tape in a solution of calcium glycerophosphate. They observed that the $c$-axis of the hydroxyapatite crystals aligned parallel to the collagen fibers. Although their work was not intended to manufacture materials but to try to verify a proposed mechanism of calcification, the technique was utilized by others to produce collagen-calcium phosphate composites for biomedical applications. ${ }^{10)-14)}$ Figure 2 shows an example. The alkaline phosphatase-mediated collagencalcium phosphate composites were shown to support the attachment and growth of fibroblast cells ${ }^{12)}$ and to promote the differentiation of preosteoblast cells. ${ }^{13)}$ They also showed bioresorbability when implanted in the backs of Wistar rats, ${ }^{11}$ ) and promoted the formation of bone-like tissue in the root canal of a dog. ${ }^{14)}$

These are good examples of applications which make full use of an advantage unique to enzyme-mediated ceramic synthesis: the use of alkaline phosphatase enables the precipitation of hydroxyapatite under ambient temperatures thereby avoiding unnecessary heat damage to reconstituted collagen.

In the early days, the deposition of calcium phosphate took a long time, as its rate was determined by the diffusion of reactants through a network of reconstituted collagen sponge. The reaction took several days, until ca. 60 mass $\%$ of calcium phosphate was deposited in the composite. ${ }^{11)}$ The time required was shortened to one day by continuous replenishment of the reactants under mechanical stirring of the calcium glycerophosphate solution. ${ }^{14)}$

\subsection{Urease}

Urease catalyzes the hydrolysis of urea into ammonia and carbonic acid (Eq. 4): 


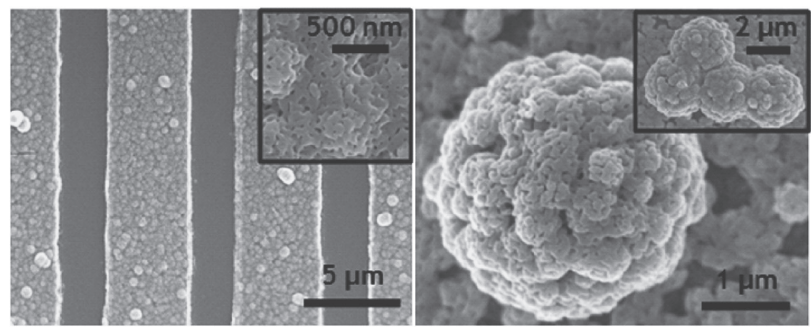

Fig. 3. Urease-mediated $\mathrm{CaCO}_{3}$ thin films deposited (left) in line patterns and (right) on polystyrene beads. Reprint from Ref. 28 with permission from American Chemical Society.

$$
\mathrm{H}_{2} \mathrm{NCONH}_{2}+2 \mathrm{H}_{2} \mathrm{O} \rightarrow 2 \mathrm{NH}_{3}+\mathrm{H}_{2} \mathrm{CO}_{3}
$$

The reaction 4 , which is well known as a homogeneous precipitation technique utilizing the spontaneous hydrolysis of urea above ca. $340 \mathrm{~K}$, can be made to take place at room temperature by employing urease.

The optimum $\mathrm{pH}$ range of urease is relatively wide from 3 to 8 . Either ammonia or carbon dioxide can act as a precipitant. Urease-mediated ceramic products reported so far include hydroxides, carbonates, hydroxyapatite, and oxides.

Unuma et al. immobilized urease in alginate gel, W/O emulsion, and polymer microspheres to precipitate basic aluminum sulfate, iron hydroxide and hydroxyapatite on or in the templates, to prepare porous alumina, ${ }^{26)}$ hollow alumina microspheres, ${ }^{25)}$ and hollow particles of magnetite, ${ }^{22)}$ and hydroxyapatite. $^{38)}$ With the aim of developing materials for cancer treatment, Kawashita et al. prepared porous particles of magnetite ${ }^{21)}$ and $\mathrm{Y}_{2} \mathrm{O}_{3}{ }^{39)}$ by using immobilized urease in gel template spheres. Enzyme-mediated precipitation has facilitated the preparation of hollow ceramic microspheres several tens of microns in diameter, which was previously found difficult.

Mediation by immobilized urease can also be used to prepare ceramic coatings. Unuma et al. immobilized urease onto the surface of silk fabric ${ }^{34)}$ and the inner surface of poly(L-lactic acid) sponge ${ }^{32}$ ) with water soluble carbodiimide (WSC) and precipitated a layer of hydroxyapatite onto the immobilized urease. The hydroxyapatite coatings were shown to enhance the proliferation of osteoblast-like cells. ${ }^{35)}$

Yeom et al. ${ }^{28)}$ prepared physically immobilized urease multilayers by alternately coating negatively charged urease and positively charged poly(diallyldimethylammonium chloride) (PDAC) on a silicon wafer, polystyrene beads, and polyurethane, and deposited amorphous $\mathrm{CaCO}_{3}$ layers on them (Fig. 3). They reported that, after conversion of the amorphous $\mathrm{CaCO}_{3}$ to calcite in a humidity-controlling chamber, the calcite adopted a (104) orientation. Urease activity was found to increase as the number of alternately stacked urease layers increased.

An interesting application of urease was reported by Hamaya et al., ${ }^{18)-20)}$ who prepared magnetite particles by urease mediation from a solution containing $\mathrm{FeCl}_{2}, \mathrm{KNO}_{3}$, and urea. The formation of magnetite was based on the $\mathrm{pH}$ dependence of the oxidation potential of nitrate ions; in a certain $\mathrm{pH}$ range, $\mathrm{Fe}^{2+}$ was oxidized to $\mathrm{Fe}^{3+}$ by nitrate ions, and fine particles of magnetite precipitated spontaneously.

The physical and chemical properties of urease-mediated ceramic products sometimes differ from those of products prepared under urease-free conditions. Sondi et al. ${ }^{27), 30)}$ reported that urease-mediated $\mathrm{CaCO}_{3}$ precipitated in the amorphous phase at first, and spontaneously transformed to calcite via vaterite, while the morphology of urease-mediated $\mathrm{SrCO}_{3}$

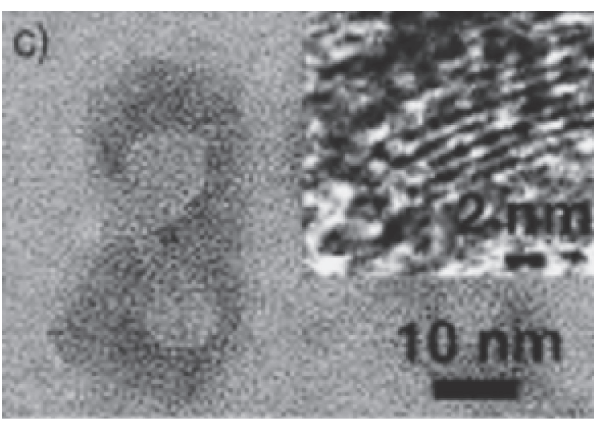

Fig. 4. Urease-core $\mathrm{ZnO}$-shell nanoparticles. Reprint from Ref. 40 with permission from Wiley-VCH Verlag GmbH\&Co.KGaA.

spontaneously evolved from spherical to rod-like. De la Rica and Matsui ${ }^{40)}$ reported that, on addition of zinc nitrate hexahydrate solution to a urease/urea solution, particles with a urease-core and a $\mathrm{ZnO}$-shell, $18 \mathrm{~nm}$ in diameter, precipitated at room temperature (Fig. 4). Although $\mathrm{Zn}(\mathrm{OH})_{2}$ is the product of the reaction of $\mathrm{Zn}^{2+}$ and $\mathrm{NH}_{3}$ in an ambient condition, it was $\mathrm{ZnO}$ that came out around urease. The investigators ascribed the formation of $\mathrm{ZnO}$ to an interaction between $\mathrm{Zn}$ ions and the urease surface.

A smart method in which urease was used in two ways at the same time was reported by Gutiérrez et al. ${ }^{36)}$ They added urease to a solution containing urea, chitosan, calcium ions and phosphate ions. When the $\mathrm{pH}$ was raised, gelation of a weakly acidic chitosan solution and precipitation of calcium phosphate took place concurrently. After uniaxial freezing and freezedrying, they prepared chitosan-calcium phosphate composites with a hierarchical pore structure. The urease they used showed activity even at $273 \mathrm{~K}$, and the composite prepared at $273 \mathrm{~K}$ contained dispersed amorphous calcium phosphate.

$\mathrm{Yu}$ et al. ${ }^{29)}$ prepared urease-containing polypeptide capsules by impregnating mesoporous silica spheres with urease and coating the spheres layer by layer with poly(L-lysine) and poly(Lglutamic acid), before dissolving the silica in a $\mathrm{HF} / \mathrm{NH}_{4} \mathrm{~F}$ solution. The urease-containing capsules were placed in a solution of urea and $\mathrm{CaCl}_{2}$ to obtain spherical calcite/vaterite particles.

\subsection{Other enzymes in category I}

Carbonic anhydrase catalyzes the dehydration of carbonate ions and the hydration of carbon dioxide (Eq. 5):

$$
\mathrm{H}_{2} \mathrm{CO}_{3} \rightleftarrows \mathrm{H}_{2} \mathrm{O}+\mathrm{CO}_{2}
$$

When carbonic anhydrase is added to a solution containing metal ions in a $\mathrm{CO}_{2}$-containing atmosphere, metal carbonates or metal carbonate phosphates precipitate in the solution. McConnell et al. ${ }^{1)}$ reported the formation of carbonate hydroxyapatite when carbonic anhydrase was added to a solution containing sodium phosphate and calcium chloride in a $\mathrm{CO}_{2}$ atmosphere, or to heat-treated saliva. Abe et al. ${ }^{43)}$ prepared an artificial enzyme mimicking the active center of carbonic anhydrase based on a zinc-imidazole complex, and found that the artificial enzyme mediated the precipitation of vaterite, ca. $1 \mu \mathrm{m}$ in diameter, from a $\mathrm{NaHCO}_{3} / \mathrm{Ca}\left(\mathrm{NO}_{3}\right)_{2}$ solution.

Lipase can catalyze the liberation of oxalic acid from oxalate esters, which allows precipitation of metal oxalates. ${ }^{42)}$ To lower the $\mathrm{pH}$ of a solution, glucose oxidase, which catalyzes the formation of gluconic acid from glucose, may be used. ${ }^{41)}$ The hydrogen peroxide by-product must be eliminated with catalase (Eqs. 6 and 7): 

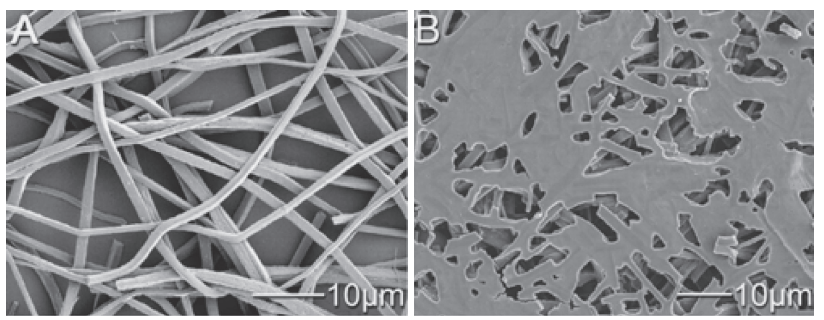

Fig. 5. Purified silicatein filaments (A) without and (B) with $\mathrm{TiO}_{2}$ deposits from Ti-BADLH. Reprint from Ref. 50 with permission from American Chemical Society.

$$
\underset{\text { (glucose) }}{\mathrm{C}_{6} \mathrm{H}_{12} \mathrm{O}_{6}}+\mathrm{O}_{2}+\mathrm{H}_{2} \mathrm{O} \underset{\text { (gluconic acid) }}{\rightarrow} \mathrm{C}_{6} \mathrm{H}_{12} \mathrm{O}_{7}+\mathrm{H}_{2} \mathrm{O}_{2}
$$

$$
2 \mathrm{H}_{2} \mathrm{O}_{2} \rightarrow 2 \mathrm{H}_{2} \mathrm{O}+\mathrm{O}_{2}
$$

\subsection{Silicatein}

Silicatein, which is intimately associated with biosilica in the spicules of sponge Tethya aurantia, was identified in 1998 by Morse's group. In the next year, the same group found that silicatein was divided into various subunits, which catalyzed the formation of silica from TEOS in vitro, ${ }^{47)}$ and they claimed that the active sites for silica formation were hydrogen-bonded Ser/His and Cys/His residues. These reports, to a large extent, resulted in the emergence of the field of silicatein-mediated ceramic synthesis.

Thin silica layers were coated on the surfaces of nano-sized $\gamma-\mathrm{Fe}_{2} \mathrm{O}_{3}$ or hydroxyapatite particles after the modification of those surfaces with silicatein, ${ }^{48), 49)}$ utilizing the site-selective nature of enzyme-mediated ceramic synthesis. In addition, silicatein was found to be active in the synthesis of $\mathrm{TiO}_{2},{ }^{50)-52)}$ $\mathrm{ZrO}_{2},{ }^{51)} \mathrm{Ga}_{2} \mathrm{O}_{3},{ }^{53)}$ or $\mathrm{BaTiOF}_{4},{ }^{54)}$ which is of significance because site-selective precipitation of $\mathrm{SiO}_{2}$ or $\mathrm{TiO}_{2}$ has been difficult by conventional techniques. An example of silicateinmediated $\mathrm{TiO}_{2}$ is shown in Fig. 5. Silicatein-mediated titania precipitated from Ti-BALDH showed different phase evolution behavior from titania precipitated by alkali addition. ${ }^{50)}$

\subsection{Lysozyme}

While investigating substances that promoted the condensation of silicic acid, Coradin, Livage, and co-workers ${ }^{68), 69)}$ found that peptides and proteins containing large amounts of lysine and arginine residues are effective in this regard. Based on these findings, they discovered in 2003 that lysozyme and bovine serum albumin (BSA) are especially suitable for silicate condensation. ${ }^{55), 56)}$ These reports prompted materials scientists to use lysozyme for ceramic deposition. Lysozyme basically catalyzes the hydrolysis of polysaccharides, with silicate condensation activity as a side-effect. Luckarift et al. ${ }^{57)}$ found that lysozyme promotes the formation not only of silica but also of $\mathrm{TiO}_{2}$ from hexafluorotitanate or titanium lactate complexes. Lysozyme-mediated silica was found to be suitable as a support for enzyme immobilization; Ramanathan et al. ${ }^{59)}$ reported that organophosphate hydrolase supported on lysozyme-mediated silica was found to have a longer life time than a conventional support. An interesting application of lysozyme in controlling the morphology of silica was investigated by Shiomi et al., ${ }^{60)}$ who prepared hollow silica microspheres by subjecting a solution of lysozyme and TEOS to ultrasonication (Fig. 6). Lysozyme was found to be effective in synthesizing $\mathrm{Bi}_{2} \mathrm{~S}_{3}$ from a solution of bismuth nitrate and thiourea. ${ }^{62)}$ The approach of Coradin and

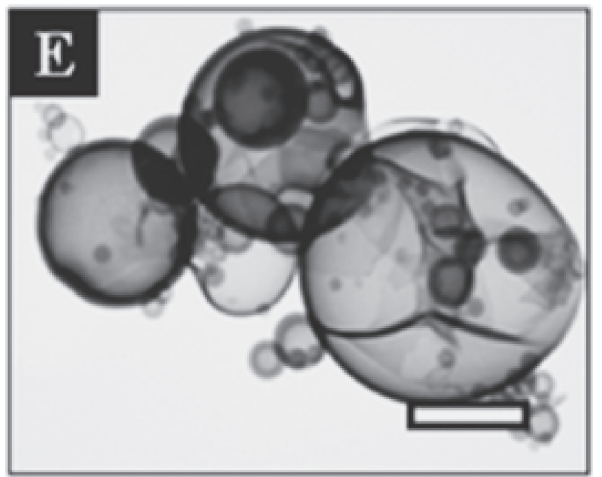

Fig. 6. Lysozyme-mediated silica hollow particles, scale bar: $3 \mu \mathrm{m}$. Reprint from Ref. 60 with permission from American Chemical Society.

Livage, which focused on searching for effective biocatalysts based on amino acid sequences, seems to have had a strong impact on peptide-mediated ceramic precipitation, as described in Section 2.7.

\subsection{Other enzymes in category II}

A series of hydrolases, including lipases and peptidases, were found to catalyze the hydrolysis and condensation of alkoxysilanes ${ }^{63), 65)-67)}$ and titanium complexes. ${ }^{64), 65)}$ As may be expected, enzyme activity in the condensation of silanols to form siloxanes strongly depends on the origin of the enzyme. ${ }^{66)}$ Usually, enzymes are active in aqueous solutions. However, Kato et al. ${ }^{67)}$ found that some enzymes catalyzed silica formation from TEOS in an ionic liquid, and the resultant silica encapsulated the enzymes themselves, forming silica-enzyme composites. Interestingly, these composites showed higher catalytic activity than free enzymes in the hydrolysis and condensation of trimethylethoxysilane.

Glucose oxidase and catalase were found to catalyze $\mathrm{TiO}_{2}$ formation, ${ }^{61)}$ but resulted in different crystalline phases: glucose oxidase gave rutile, while catalase gave anatase.

\subsection{Peptide-mediated ceramic synthesis and re- lated techniques}

Although it does not involve enzymes, we will give a brief overview of a closely related method of peptide-mediated ceramic synthesis. Silaffin, a protein isolated from diatoms, is not an enzyme but acts in a similar manner to silicatein to precipitate $\mathrm{SiO}_{2}$ or $\mathrm{TiO}_{2}{ }^{70)-72)}$ The silica-precipitating ability of silaffin was attributed to the presence of a polycation peptide, ${ }^{71)}$ $\mathrm{H}_{2} \mathrm{~N}$-SSKKSGSYSGSKGSKRRIL-COOH, named R5. A short time later, the synthesis of silica from a silicic acid solution ${ }^{73)}$ and the synthesis of $\mathrm{TiO}_{2}$ from Ti-BALDH ${ }^{74)}$ were attempted using R5 peptide.

Single amino acids such as lysine and serine, polypeptides such as polylysine and polyserine, and other synthetic oligopeptides were found to be effective in the synthesis of silica from TEOS. ${ }^{75)}$ Although the products of these early studies were mostly featureless micron-sized aggregates of nano-sized primary particles, attempts to control the morphology of the products were soon made. Gautier et al. ${ }^{76)}$ prepared silica nanotubes by immobilizing poly(L-lysine) (PLL) in the pores of polycarbonate membrane and then depositing silica along the inner walls of the pores. Goldberg et al. ${ }^{77)}$ coated the surface of dentin with PLLmediated silica to modify its permeability. Cha et al. ${ }^{78)}$ attempted to control the morphology of silica by changing the atmosphere 

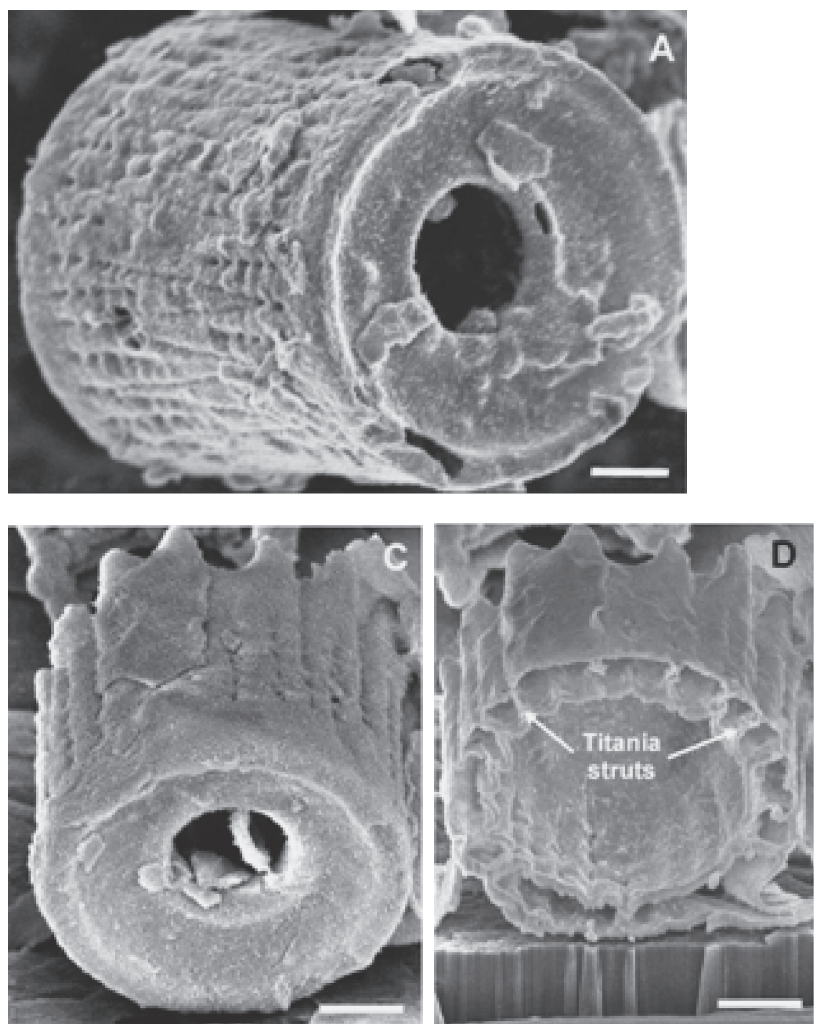

Fig. 7. Freestanding $\mathrm{TiO}_{2}$ replicating (A) a complete and (C) a partial frustule. The picture (D) shows a cross-section of specimen (C) to show the replication of titania struts. Scale bars: $2 \mu \mathrm{m}$. Reprint from Ref. 80 with permission from American Chemical Society.

in which certain block copolypeptides interacted with TEOS. Poly(L-cycteine $30-b$-L-lysine 200 ) was found to promote the formation of spherical silica in a nitrogen atmosphere, while column-shaped amorphous silica was formed in air.

Simple molecules including protamine, ${ }^{79), 80}$ cycteamine, ${ }^{81)}$ cyclic lanreotide, ${ }^{82)}$ and ethyleneamine ${ }^{83)}$ have also been found to catalyze the formation of $\mathrm{SiO}_{2}$ and $\mathrm{TiO}_{2}$. Liang et al. ${ }^{79}$ ) showed that protamine-mediated titania was a good support for yeast alcohol dehydrogenase (YEAD); the supported YEAD showed excellent stability against temperature, $\mathrm{pH}$, and recycling. Fang et al. ${ }^{80)}$ coated diatom frustule (biosilica) with $\mathrm{TiO}_{2}$ using protamine, and reported that the freestanding $\mathrm{TiO}_{2}$, replicating the morphology of the biosilica (Fig. 7), showed electrochemical hydrogen detection properties. Roth et al. ${ }^{81)}$ fabricated silica patterns by forming a pattern of adsorbed cysteamine on a silicon wafer and then depositing silica (Fig. 8). Pouget et al. ${ }^{82)}$ prepared bundles of silica nanotubes $30 \mathrm{~nm}$ thick and several microns long by adding cyclic lanreotide to TEOS; partially hydrolyzed TEOS and cyclic lanreotide self-assembled into nanotubes. Various types of solid, including $\mathrm{PbSe},{ }^{84)}$ $\mathrm{BaTiO}_{3},{ }^{85), 86)} \mathrm{CaMoO}_{4},{ }^{87)} \mathrm{Pt},{ }^{88)}$ and $\mathrm{Ni}^{89}$ have been synthesized using appropriate peptides during the last decade.

Amines, polyamines, ${ }^{90), 91)}$ and poly(ethyleneimine $)^{92), 93)}$ are also capable of catalyzing the formation of silica and titania. There is a considerable body of work regarding peptide- and polymer-mediated ceramic precipitation, and comprehensive reviews are available. ${ }^{3-8)}$ The line between enzyme-mediated and peptide-mediated precipitation techniques is quite obscure, as are the lines between other polymer-mediated techniques. However, we will not delve into the non-enzyme area any further.

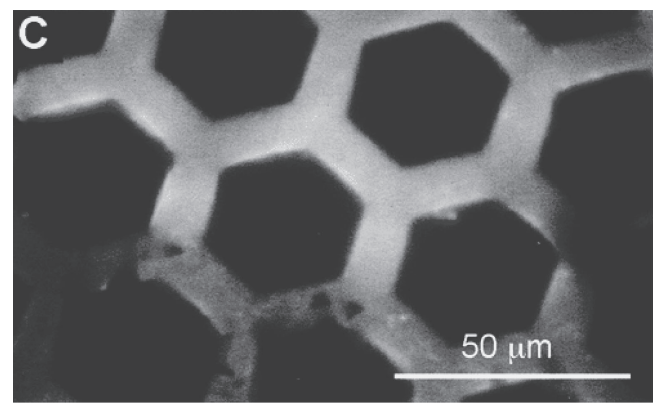

Fig. 8. Cysteamine-mediated silica patterned with microcontact printing of cysteamine on a silicon wafer. Reprint from Ref. 81 with permission from American Chemical Society.

\subsection{Enzymes in living microbes}

Sastry and co-workers have reported that a kind of fungus, Fusarium oxysporum, mediates the extracellular formation of $\mathrm{CdS}$ from $\mathrm{CdSO}_{4},{ }^{94)}$ intracellular $\mathrm{Ag}$ nanoparticles from $\mathrm{AgNO}_{3},{ }^{95)} \mathrm{ZrO}_{2}$ from $\left[\mathrm{ZrF}_{6}\right]^{2-},{ }^{26)}$ and hollow $\mathrm{SiO}_{2}$ nanoparticles from sand. ${ }^{97)}$ Although the exact enzymes or proteins responsible for ceramic synthesis were not identified, they speculated that a type of reductase or cationic protein might be playing a key role.

\section{Concluding remarks and future outlook}

The finding that enzymes, amines, and polypeptides can mediate ceramic precipitation has led to the development of a new technique of ceramic synthesis which takes place under mild conditions and allows control of morphology. The nature of enzyme-mediated ceramic precipitates sometimes differs from that of physicochemically derived ceramic precipitates in terms of morphology, crystalline phase, and structural evolution upon heating.

In general, enzyme-mediated ceramic precipitates are aggregates of nanoparticles, have low crystallinity, and contain large amounts of hydration water. The types of ceramic precipitates are limited to those which can precipitate out of aqueous solutions; so far, hydroxides, carbonates, phosphates, sulfides, hydrated oxides and metals have been synthesized. Halides may be precipitated but nitrides or carbides are not likely to be synthesized unless the precipitates are subjected to subsequent nitridation or carbide formation. Enzyme-mediated ceramic synthesis allows us to make coatings and patterns and to fabricate composites of ceramics with heat-sensitive polymers or proteins. When considering the practical application of enzymemediated ceramic synthesis, we should make use of the unique characteristics of this method. In particular, enzyme-mediated hydroxyapatite-based biomaterials have been used in animal tests and have achieved successful outcomes. One possible reason for this is that enzyme-mediated hydroxyapatite is readily soluble to body fluids due to its low crystallinity, and the release of calcium ions may cause desirable effects, such as promoting the differentiation of osteoblastic cells as reported by Jung et al. ${ }^{98)}$ Enzyme-mediated hydroxyapatite-based biomaterials may become the first successful example of practical application of this technique if the biological safety of the enzymes and reagents used is guaranteed.

Additional potential applications of this technique include the preparation of supports for enzyme immobilization, enzyme sensors, nanoparticles for quantum dots, hollow ceramic microspheres, nanotubes, 2D ceramic patterns, and ceramic coatings. As demonstrated by Fang et al., ${ }^{80)}$ replication of the morphology 
and microstructure of biominerals may be facilitated by using enzymes or peptides.

Although the selection of appropriate enzymes for specific ceramic preparations still depends on trial and error or serendipity, the selection of pertinent peptides is easier due to the availability of peptide library screening techniques. ${ }^{99), 100)}$

It should be noted that most papers referred in this article were published after the year 2000. This suggests that enzyme- and peptide-mediated ceramic synthesis techniques are on the frontier of rich vein of exploration. A single example of practical application of these techniques should accelerate exploration considerably. Collaborative and interdisciplinary work among scientists in the areas of chemistry, biology, physics, agriculture, materials science, and others will be important in this regard, allowing the creation of exquisitely designed materials and the establishment of process to develop genuinely smart materials.

\section{References}

1) D. McConnell, W. J. Frajola and D. W. Deamer, Science, 133, 281-282 (1961)

2) K. Shimizu, J. Cha, G. D. Stucky and D. E. Morse, Proc. Natl. Acad. Sci. U.S.A., 95, 6234-6238 (1998).

3) L. Betancor and H. R. Luckarift, Trends Biotechnol., 26, 566572 (2008).

4) M. B. Dickerson, K. H. Sandhage and R. R. Naik, Chem. Rev., 108, 4935-4978 (2008).

5) C.-L. Chen and N. L. Rosi, Angew. Chem., Int. Ed., 49, 1924 1942 (2010).

6) S. V. Patwardhan, S. J. Clarson and C. C. Perry, Chem Commun. (Camb.), 2005, 1113-1121 (2005).

7) Q. Sun, E. G. Vrieling, R. A. van Santen and N. A. J. M. Sommerdijk, Curr. Opin. Solid State Mater. Sci., 8, 111-120 (2004).

8) M. M. Tomczak, J. M. Slocik, M. O. Stone and R. R. Naik, Biochem. Soc. Trans., 35, 512-515 (2007).

9) E. Banks, S. Nakajima, L. C. Shapiro, O. Tilevitz, J. R. Alonzo and R. R. Chianelli, Science, 198, 1164-1166 (1977).

10) Y. Doi, T. Horiguchi, S.-H. Kim, Y. Moriwaki, N. Wakamatsu, M. Adachi, K. Ibaraki, K. Moriyama, S. Sasaki and H. Shimokawa, Arch. Oral Biol., 37, 15-21 (1992).

11) Y. Doi, T. Horiguchi, Y. Moriwaki, H. Kitago, T. Kajimoto and Y. Iwayama, J. Biomed. Mater. Res., 31, 43-49 (1996).

12) K. Yamauchi, T. Goda, N. Takeuchi, H. Einaga and T. Tanabe, Biomaterials, 25, 5481-5489 (2004).

13) O. Tomomatsu, A. Tachibana, K. Yamauchi and T. Tanabe, J. Ceram. Soc. Japan, 116, 10-13 (2008).

14) Y. Takenaka, M. Iijima, S. Kawano, Y. Akita, T. Yoshida, Y. Doi and I. Sekine, J. Ceram. Soc. Japan, 116, $92-95$ (2008).

15) C. Hoffman, C. Zollfrank and G. Ziegler, J. Mater. Sci.: Mater. Med., 19, 907-915 (2008).

16) E. D. Spoerke, S. G. Anthony and S. I. Stupp, Adv. Mater., 21, 425-430 (2009)

17) H. Tanaka and D. Ihata, Mater. Res. Bull., 45, 103-108 (2010).

18) T. Hamaya and K. Horikoshi, Agric. Biol. Chem., 53, 851852 (1989).

19) T. Hamaya and K. Horikoshi, Agric. Biol. Chem., 53, 19891990 (1989).

20) T. Hamaya, T. Takizawa, H. Hidaka and K. Horikoshi, $J$. Chem. Eng. Jpn., 26, 223-224 (1993).

21) M. Kawashita, K. Sadaoka, T. Kokubo, T. Saito, M. Takano, N. Araki and M. Hiraoka, J. Mater. Sci.: Mater. Med., 17, 605-610 (2006)

22) J. Zhao, H. Sekikawa, T. Kawai and H. Unuma, J. Ceram. Soc. Japan, 117, 344-346 (2009).

23) H. Unuma, S. Kato, T. Ota and M. Takahashi, Adv. Powder Technol., 9, 181-190 (1998).
24) F. Kara and G. Sahin, J. Eur. Ceram. Soc., 20, 689-694 (2000).

25) S. Kato, T. Makino, H. Unuma and M. Takahashi, J. Ceram. Soc. Japan, 109, 369-371 (2001).

26) H. Unuma, Y. Hirose, M. Ito and K. Watanabe, J. Ceram. Soc. Japan, 112, 409-411 (2004).

27) I. Sondi and E. Matijević, J. Colloid Interface Sci., 238, 208214 (2001).

28) B. Yeom and K. Char, Chem. Mater., 22, 101-107 (2010).

29) A. Yu, I. Gentle, G. Lu and F. Caruso, Chem. Commun. (Camb.), 2006, 2150-2152 (2006).

30) I. Sondi and E. Matijević, Chem. Mater., 15, 1322-1326 (2003).

31) J. Nozaki, M. Aizawa, H. Uchida, K. Itatani, H. Suemasu, A. Nozue, I. Okada, M. Matsumoto, H. Matsumoto and Y. Toyama, Key Eng. Mater., 240-242, 603-606 (2003).

32) H. Unuma and A. Ito, Key Eng. Mater., 309-311, 667-670 (2006).

33) H. Unuma, Int. J. Appl. Ceram. Technol., 4, 14-21 (2007).

34) H. Unuma, M. Hiroya and A. Ito, J. Mater. Sci.: Mater. Med., 18, 987-990 (2007)

35) Z. Pan, X. Huang, D. Yang, H. Unuma and W. Yan, Key Eng. Mater., 330-332, 707-710 (2007).

36) M. C. Gutiérrez, M. Jobbágy, M. L. Ferrer and F. del Monte, Chem. Mater., 20, 11-13 (2008).

37) I. Ortega, M. Jobbágy, M. L. Ferrer and F. del Monte, Chem. Mater., 20, 7368-7370 (2008).

38) T. Kawai, H. Sekikawa and H. Unuma, J. Ceram. Soc. Japan, 117, 340-343 (2009).

39) M. Kawashita, Y. Takayama, T. Kokubo, G. H. Takaoka, N. Araki and M. Hiraoka, J. Am. Ceram. Soc., 89, 1347-1351 (2006).

40) R. de la Rica and H. Matsui, Angew. Chem., Int. Ed., 47, 5415-5417 (2008).

41) S. Kato, H. Unuma, T. Ota and M. Takahashi, J. Am. Ceram. Soc., 83, 986-988 (2000).

42) S. Kato, H. Unuma, T. Ota and M. Takahashi, Ceram. Trans., 112, 53-58 (2001).

43) S. Abe, T. Ishida, E. Yamatoya, D. Hayashi, T. Akasaka, M. Uo, F. Watari and T. Takada, Nano Biomed., 1, 51-58 (2009).

44) R. L. Brutchey and D. E. Morse, Chem. Rev., 108, 4915-4934 (2008).

45) C. C. Perry and T. Keeling-Tucker, J. Biol. Inorg. Chem., 5, 537-550 (2000).

46) D. E. Morse, Trends Biotechnol., 17, 230-232 (1999).

47) J. N. Cha, K. Shimizu, Y. Zhou, S. C. Christiansen, B. F. Chmelka, G. D. Stucky and D. E. Morse, Proc. Natl. Acad. Sci. U.S.A., 96, 361-365 (1999).

48) M. I. Shukoor, F. Natalio, H. A. Therese, M. N. Tahir, V. Ksenofontov, M. Panthöfer, M. Eberhardt, P. Theato, H. C. Schröder, W. E. G. Müller and W. Tremel, Chem. Mater, 20, 3567-3573 (2008).

49) F. Natalio, T. Link, W. E. G. Müller, H. C. Schröder, F.-Z. Cui, X. Wang and M. Wiens, Acta Biomater., 6, 3720-3728 (2010).

50) J. L. Sumerel, W. Yang, D. Kisailus, J. C. Weaver, J. H. Choi and D. E. Morse, Chem. Mater., 15, 4804-4809 (2003).

51) M. N. Tahir, P. Théato, W. E. G. Müller, H. C. Schröder, A. Borejko, S. Faiß, A. Janshoff, J. Huth and W. Tremel, Chem. Commun. (Camb.), 2005, 5533-5535 (2005).

52) M. N. Tahir, F. Natalio, H. A. Therese, A. Yella, N. Metz, M. R. Shah, E. Mugnaioli, R. Berger, P. Theato, H.-C. Schröder, W. E. G. Müller and W. Tremel, Adv. Funct. Mater, 19, 285-291 (2009).

53) D. Kisailus, J. H. Choi, J. C. Weaver, W. Yang and D. E. Morse, Adv. Mater., 17, 314-318 (2005).

$54)$ R. L. Brutchey, E. S. Yoo and D. E. Morse, J. Am. Chem. Soc., 128, 10288-10294 (2006).

55) T. Coradin, A. Coupé and J. Livage, Colloids Surf., B, 29, 
189-196 (2003)

56) T. Coradin, P. J. Lopez, C. Gautier and J. Livage, C. $R$. Palevol, 3, 443-452 (2004)

57) H. R. Luckarift, M. B. Dickerson, K. H. Sandhage and J. C. Spain, Small, 2, 640-643 (2006)

58) H. R. Luckarift, S. Balasubramanian, S. Paliwal, G. R. Johnson and A. L. Simonian, Colloids Surf., B, 58, 28-33 (2007).

59) M. Ramanathan, H. R. Luckarift, A. Sarsenova, J. R. Wild, E. K. Ramanculov, E. V. Olsen and A. L. Simonian, Colloids Surf., B, 73, 58-64 (2009).

60) T. Shiomi, T. Tsunoda, A. Kawai, F. Mizukami and K Sakaguchi, Chem. Mater., 19, 4486-4493 (2007).

61) G. Chen, M. Li, F. Li, S. Sun and D. Xia, Adv. Mater, 22, 1258-1262 (2010).

62) F. Gao, Q. Lu and S. Komarneni, Chem. Commun. (Camb.), 2005, 531-533 (2005).

63) P. Buisson, H. El Rassy, S. Maury and A. C. Pierre, J. Sol-Gel Sci. Technol., 27, 373-379 (2003).

64) K. Katagiri, H. Inami, T. Ishikawa and K. Koumoto, J. Am Ceram. Soc., 92, S181-S184 (2009).

$65)$ G. P. Smith, K. J. Baustian, C. J. Ackerson and D. L. Feldheim, J. Mater. Chem., 19, 8299-8306 (2009).

66) A. R. Bassindale, K. F. Brandstadt, T. H. Lane and P. G. Taylor, J. Inorg. Biochem., 96, 401-406 (2003).

67) K. Kato, S. Nakagaki, M. Nishida and K. Hirao, J. Ceram Soc. Japan, 119, 140-143 (2011).

68) T. Coradin, O. Durupthy and J. Livage, Langmuir, 18, 23312336 (2002)

69) T. Coradin and J. Livage, Colloids Surf., B, 21, 329-336 (2001).

70) N. Kröger, R. Deutzmann and M. Sumper, Science, 286, 1129-1132 (1999).

71) N. Kröger, S. Lorenz, E. Brunner and M. Sumper, Science, 298, 584-586 (2002).

72) N. Kröger, M. B. Dickerson, G. Ahmad, Y. Cai, M. S. Haluska, K. H. Sandhage, N. Poulsen and V. C. Sheppard Angew. Chem., Int. Ed., 45, 7239-7243 (2006).

73) H. R. Luckarift, J. C. Spain, R. R. Naik and M. O. Stone, Nat. Biotechnol., 22, 211-213 (2004).

74) S. L. Sewell and D. W. Wright, Chem. Mater., 18, 3108-3113 (2006).

75) L. Sudheendra and A. R. Raju, Mater. Res. Bull., 37, 151-159 (2002)

76) C. Gautier, P. J. Lopez, J. Livage and T. Coradin, J. Colloid Interface Sci., 309, 44-48 (2007).

77) A. J. Goldberg, M. C. Advincula, T. Komabayashi, P. A. Patel, P. T. Mather, D. G. Goberman and R. B. Kozemi, J. Dent. Res., 88, 377-381 (2009).

78) J. N. Cha, G. D. Stucky, D. E. Morse and T. J. Deming, Nature, 403, 289-292 (2000).
79) Y. Jiang, Q. Sun, Z. Jiang, L. Zhang, J. Li, L. Li and X. Sun, Mater. Sci. Eng., C, 29, 328-334 (2009).

80) Y. Fang, Q. Wu, M. B. Dickerson, Y. Cai, S. Shian, J. D. Berrigan, N. Poulsen, N. Kröger and K. H. Sandhage, Chem. Mater., 21, 5704-5710 (2009).

81) K. M. Roth, Y. Zhou, W. Yang and D. E. Morse, J. Am. Chem. Soc., 127, 325-330 (2005).

82) E. Pouget, E. Dujardin, A. Cavalier, A. Moreac, C. Valéry, V. Marchi-Artzner, T. Weiss, A. Renault, M. Paternostre and F. Artzner, Nat. Mater., 6, 434-439 (2007).

83) D. J. Belton, S. V. Patwardhan and C. C. Perry, J. Mater. Chem., 15, 4629-4638 (2005).

84) M. Shi, W. Su and H. Matsui, Nanoscale, 2, 2373-2376 (2010).

85) G. Ahmad, M. B. Dickerson, Y. Cai, S. E. Jones, E. M. Ernst, J. P. Vernon, M. S. Haluska, Y. Fang, J. Wang, G. Subramanyam, R. R. Naik and K. H. Sandhage, J. Am. Chem. Soc., 130, 4-5 (2008)

86) A. R. Tao, K. Niesz and D. E. Morse, J. Mater. Chem., 20, 7916-7923 (2010).

87) G. Ahmad, M. B. Dickerson, B. C. Church, Y. Cai, S. E. Jones, R. R. Naik, J. S. King, C. J. Summers, N. Kröger and K. H. Sandhage, Adv. Mater. 18, 1759-1763 (2006).

88) L. M. Forbes, A. P. Goodwin and J. N. Cha, Chem. Mater, 22, 6524-6528 (2010).

89) L. Yu, I. A. Banerjee, M. Shima, K. Rajan and H. Matsui, Adv. Mater., 16, 709-712 (2004).

90) T. Mizutani, H. Nagase, N. Fujiwara and H. Ogoshi, Bull. Chem. Soc. Jpn., 71, 2017-2022 (1998).

91) S. V. Patwardhan and S. J. Clarson, Polym. Bull., 48, 367-371 (2002).

92) J.-J. Yuan and R.-H. Jin, Adv. Mater., 17, 885-888 (2005)

93) R.-H. Jin and J.-J. Yuan, Adv. Mater., 21, 3750-3753 (2009).

94) A. Ahmad, P. Mukherjee, D. Mandal, S. Senapati, M. I. Khan, R. Kumar and M. Sastry, J. Am. Chem. Soc., 124, 1210812109 (2002).

95) A. Ahmad, P. Mukherjee, S. Senapati, D. Mandal, M. I. Khan, R. Kumar and M. Sastry, Colloids Surf., B, 28, 313-318 (2003)

96) V. Bansal, D. Rautaray, A. Ahmad and M. Sastry, J. Mater Chem., 14, 3303-3305 (2004).

97) V. Bansal, A. Sanyal, D. Rautaray, A. Ahmad and M. Sastry, Adv. Mater., 17, 889-892 (2005)

98) G.-Y. Jung, Y.-J. Park and J.-S. Han, J. Mater. Sci.: Mater. Med., 21, 1649-1654 (2010).

99) M. B. Dickerson, S. E. Jones, Y. Cai, G. Ahmad, R. R. Naik N. Kröger and K. H. Sandhage, Chem. Mater., 20, 1578-1584 (2008).

100) S. M. Hee, J.-H. Lee, M. S. Kim, H. K. Chae and H. Myung, J. Microbiol. Biotechnol., 16, 303-307 (2006). 